\title{
Profil penyandang epilepsi di Poliklinik Saraf RSUP Prof. Dr. R.D. Kandou Manado periode Juli 2015 - Juni 2016
}

\author{
${ }^{1}$ Mughni H. Hasibuan \\ ${ }^{2}$ Corry N. Mahama \\ ${ }^{2}$ Rizal Tumewah
}

\author{
${ }^{1}$ Kandidat Skripsi Fakultas Kedokteran Universitas Sam Ratulangi Manado \\ ${ }^{2}$ Bagian Neurologi Fakultas Kedokteran Universitas Sam Ratulangi Manado \\ Email:mughnihusna@gmail.com
}

\begin{abstract}
Epilepsy is one of the most common neurological diseases that can be complicated due to behavioral, cognitive, and mental disorders. Approximately 50 million people currently live with epilepsy worldwide. Epilepsy is still a major public health problem, not only because of its health implications but also for its connotations in social, cultural, psychological, and economic life aspects. This study was aimed to obtain the profile of patients with epilepsy in the Neurology Clinic of Prof. Dr. R. D. Kandou Hospital Manado from July 2015 to June 2016. This was a descriptive retrospective study. The results showed that the number of epileptic patients was higher in males than in females. Epipleptic patients were more common in young adult age group, high school graduated, had no ocuupation yet and were still students. Majority of patients had partial seizure type (focal) epilepsy. Most epileptic patients were treated with monotherapy antiepileptic drugs. Based on the seizures, most patients had uncontrolled seizure.
\end{abstract}

Keywords: epilepsy, seizure.

\begin{abstract}
Abstrak: Epilepsi merupakan salah satu penyakit saraf yang paling umum dan dapat menjadi rumit dengan gangguan perilaku, kognitif, dan mental. Sekitar 50 juta orang saat ini hidup dengan epilepsi di seluruh dunia. Epilepsi masih masalah kesehatan masyarakat yang utama, karena bukan hanya berdampak pada kesehatan tetapi juga berdampak pada sosial, ekonomi, psikologis dan budaya. Penelitian ini bertujuan untuk memperoleh profil penyandanfn epilepsi dalam 1 tahun di Poliklinik Saraf RSUP Prof. Dr. R. D. Kandou Manado periode Juli 2015-Juni 2016. Jenis penelitian ialah deskriptif retrospektif menggunakan data penderita Epilepsi yang tercatat di rekam medik RSUP Prof. Dr. R. D. Kandou Manado periode Juli 2015 hingga Juni 2016. Hasil penelitian menunjukkan penyandang epilepsi laki-laki lebih banyak dibandingkan dengan perempuan. Terbanyak ditemukan pada golongan usia dewasa muda, lulusan SMA, belum bekerja dan masih berstatus sebagai pelajar. Penyandang epilepsi dengan jenis bangkitan parsial (fokal) paling banyak ditemukan dari pada yanng dengan jenis bangkitan umum. Pengobatan tersering yang dilakukan terhadap penyandang epilepsi ialah dengan monoterapi obat-obat anti epilepsi. Berdasarkan terkontrolnya kejang pada pasien epilepsi, lebih banyak kejang tidak terkontrol.
\end{abstract}

Kata kunci: epilepsi, kejang.

Epilepsi sudah di kenal sejak 2000 tahun sebelum Masehi. ${ }^{1}$ Epilepsi merupakan salah satu penyakit saraf yang paling umum dapat menjadi rumit dengan gangguan perilaku, kognitif, dan mental. Gangguan kognitif tersebut menurunkan kualitas hidup dan menyebabkan maladapsi sosial pasien. $^{2}$ Epilepsi masih menjadi masalah 
kesehatan masyarakat yang utama. Sekitar 50 juta orang saat ini hidup dengan epilepsi di seluruh dunia. Beberapa penelitian di negara-negara berpenghasilan rendah dan menengah menunjukkan bahwa proporsi yang jauh lebih tinggi, antara 7 dan 14 per 1000 orang. $^{3}$ Hasil penelitian yang dilakukan terhadap penyandang epilepsi di Poliklinik Saraf RSUP Prof. Dr. R. D. Kandou periode Juni 2013-Mei 2014 oleh Khasanah et al. ${ }^{4}$ mendapatkan penyandang epilepsi lebih banyak ditemukan pada laki laki dibandingkan perempuan. ${ }^{4}$

Pasien dengan epilepsi memiliki tingkat kematian lebih tinggi secara bermakna dibandingkan dengan populasi umum. ${ }^{5}$ Walaupun penyakit ini telah dikenal lama dalam masyarakat, terbukti dengan adanya istilah-istilah bahasa daerah untuk penyakit ini seperti sawan, ayan, dan lain sebagainya, tapi pengertian akan penyakit ini masih kurang bahkan salah, sehingga penyandang epilepsi digolongkan dalam penyakit gila, kutukan, dan turunan sehingga tidak diobati atau bahkan disembunyikan. Akibatnya banyak penyandang epilepsi yang tidak terdiagnosis dan mendapat pengobatan yang tidak tepat sehingga menimbulkan dampak klinik dan psikososial yang merugikan baik bagi penyandang maupun keluarganya. ${ }^{1}$

Berdasarkan uraian diatas, maka peneliti tertarik untuk melakukan penelitian lanjutan mengenai profil penyandang epilepsi di Poliklinik Saraf RSUP Prof. Dr. R. D. Kandou Manado periode Juli 2015 hingga Juni 2016.

\section{METODE PENELITIAN}

Jenis penelitian ini ialah deskriptif retrospektif dengan menggunakan data penyandang epilepsi yang tercatat di rekam medik RSUP Prof. Dr. R. D. Kandou Manado. Penelitian dilakukan di Poliklinik Saraf RSUP Prof. Dr. R. D. Kandou Manado. Populasi ialah seluruh pasien epilepsi yang datang di Poliklinik Saraf RSUP Prof. Dr. R. D. Kandou Manado. Sampel yang digunakan ialah pasien epilepsi yang datang di Poliklinik Saraf RSUP Prof. Dr. R. D. Kandou Manado periode Juli 2015-Juni 2016 dan memenuhi kriteria inklusi yaitu memiliki catatan rekam medik, meliputi: biodata pasien (nama, umur, jenis kelamin), status kesehatan pasien (terkontrol atau tidaknya kejang, terapi pengobatan), dan status sosial ekonomi (pendidikan, pekerjaan).

\section{HASIL PENELITIAN}

Berdasarkan hasil penelitian yang dilakukan terhadap penyandang epilepsi di Poliklinik Saraf RSUP Prof. Dr. R. D. Kandou periode Juli 2015-Juni 2016 diperoleh data yang disajikan dalam bentuk tabel distribusi frekuensi.

Pada distribusi berdasarkan jenis kelamin didapatkan jumlah penyandang epilepsi laki-laki $(54,43 \%)$ lebih banyak daripada perempuan $(45,57 \%)$ (Tabel 1).

Tabel 1. Distribusi penyandang epilepsi berdasarkan jenis kelamin.

\begin{tabular}{ccc}
\hline Jenis kelamin & N & \% \\
\hline Laki-laki & 86 & 54,4 \\
Perempuan & 72 & 45,6 \\
Total & 158 & 100 \\
\hline
\end{tabular}

Tabel 2 memperlihatkan bahwa pada periode Juli 2015-Juni 2016 golongan usia 15-24 tahun yang terbanyak menyandang epilepsi yaitu 38 orang (24\%) sedangkan golongan usia 65-74 tahun merupakan yang paling sedikit yaitu 3 orang $(1,9 \%)$

Tabel 2. Distribusi penyandang epilepsi berdasarkan usia.

\begin{tabular}{ccc}
\hline $\begin{array}{c}\text { Golongan usia } \\
\text { (tahun) }\end{array}$ & $\mathbf{N}$ & $\mathbf{\%}$ \\
\hline $0-4$ & 6 & 3,8 \\
$5-14$ & 33 & 20,8 \\
$15-24$ & 38 & 24 \\
$25-34$ & 22 & 14 \\
$35-44$ & 24 & 15,2 \\
$45-44$ & 22 & 14 \\
$55-64$ & 10 & 6,3 \\
$65-74$ & 3 & 1,9 \\
$>75$ & 0 & 0 \\
Total & 158 & 100 \\
\hline
\end{tabular}

Berdasarkan Tabel 3 diperoleh tingkat pendidikan terakhir SMA paling banyak 
mengalami epilepsi yaitu sebanyak 54 orang $(34,2 \%)$; juga ditemukan 2 orang yang tidak sekolah (Tabel 3).

Tabel 3. Distribusi penyandang epilepsi berdasarkan tingkat pendidikan .

\begin{tabular}{lcc}
\hline Tingkat pendidikan & N & \% \\
\hline Belum sekolah & 8 & 5 \\
SD & 45 & 28,5 \\
SMP & 33 & 20,9 \\
SMA & 54 & 34,2 \\
Sarjana & 16 & 10,1 \\
Tidak sekolah & 2 & 1,3 \\
Total & 158 & 100 \\
\hline
\end{tabular}

Tabel 4 memperlihatkan bahwa epilepsi paling banyak ditemukan pada golongan pelajar yaitu sebanyak 51 orang $(32,3 \%)$ dan kedua tertinggi ialah yang tidak bekerja $(12,7 \%)$.

Tabel 4. Distribusi penyandang epilepsi berdasarkan jenis pekerjaan.

\begin{tabular}{ccc}
\hline Jenis pekerjaan & $\mathbf{N}$ & $\mathbf{\%}$ \\
\hline Pelajar & 51 & 32,3 \\
Mahasiswa & 9 & 5,7 \\
PNS & 10 & 6,3 \\
Pegawai Swasta & 21 & 13,3 \\
Wiraswasta & 6 & 3,8 \\
Pensiunan & 1 & 0,6 \\
IRT & 22 & 13,9 \\
Petani & 13 & 8,2 \\
Buruh & 5 & 3,2 \\
Tidak Bekerja & 20 & 12,7 \\
Total & 158 & 100 \\
\hline
\end{tabular}

Tabel 5 memperlihatkan bahwa sebanyak 3 penyandang epilepsi $(2 \%)$ dengan kejang terkontrol sedangkan 155 penyandang epilepsi $(58,5 \%)$ dengan kejang yang tidak terkontrol.

Tabel 5. Distribusi penyandang epilepsi berdasarkan kejang terkontrol atau tidak.

\begin{tabular}{ccc}
\hline Jenis kontrol & $\mathbf{N}$ & $\mathbf{\%}$ \\
\hline Terkontrol & 3 & 2 \\
\hline Tak Terkontrol & 155 & 98 \\
\hline Total & 158 & 100 \\
\hline
\end{tabular}

Tabel 6 memperlihatkan bahwa 119 penyandang epilepsi $(75,3 \%)$ dengan jenis bangkitan fokal sedangkan yang mengalami bangkitan umum sebanyak 39 orang $(24,7 \%)$.

Tabel 6. Distribusi penyandang epilepsi berdasarkan jenis bangkitan.

\begin{tabular}{ccc}
\hline Jenis bangkitan & $\mathbf{N}$ & $\mathbf{\%}$ \\
\hline Parsial/Fokal & 119 & 75,3 \\
Umum & 39 & 24,7 \\
Tak tergolongkan & 0 & 0 \\
Total & 158 & 100 \\
\hline
\end{tabular}

Tabel 7 memperllihatkan bahwa terapi yang paling banyak diberikan pada penyandang epilepsi yaitu fenitoin $(53,2 \%)$, diikuti asam valproate $(21,5 \%)$.

Tabel 7. Distribusi penyandang epilepsi berdasarkan terapi yang diberikan.

\begin{tabular}{lcc}
\hline \multicolumn{1}{c}{ Jenis terapi } & N & \% \\
\hline Fenitoin & 84 & 53,2 \\
Carbamazepine & 16 & 10,1 \\
Asam valproate & 34 & 21,5 \\
Fenobarbital & 3 & 1,9 \\
Levetiracetam & 2 & 1,2 \\
Carbamazepine + fenitoin & 9 & 5,70 \\
Carbamazepine + asam valproate & 2 & 1,2 \\
Fenitoin + asam valproate & 7 & 4,4 \\
Levetiracetam + asam valproate & 1 & 0,6 \\
Total & 158 & 100 \\
\hline
\end{tabular}

\section{BAHASAN}

Dari hasil penelitian secara retrospekif pada penyandang epilepsi yang datang ke Poliklinik Saraf RSUP Prof. DR. R. D. Kandou periode Juli 2015-Juni 2016 terdapat sebanyak 297 pasien. Dari 297 pasien tersebut, hanya 158 pasien yang memenuhi kriteria inklusi.

Distribusi berdasarkan jenis kelamin mremperlihatkan jumlah penyandang epilepsi pada laki-laki (54,43\%) lebih banyak daripada perempuan $(45,57 \%)$. Hasil penelitian ini sesuai dengan prevalensi epilepsi berdasarkan penelitian yang dilakukan pada tahun-tahun sebelumnya namun angka kejadiannya yang meningkat. Pada tahun 2013 distribusi berdasarkan jenis kelamin didapatkan jumlah penyandang epilepsi laki-laki sebanyak 58 orang $(57,4 \%)$ dan jumlah 
penyandang epilepsi perempuan sebanyak 43 orang $(42,6 \%)$. Hasil tersebut menunjukkan bahwa pasien dengan epilepsi pada tahun 2016 mengalami peningkatan jumlah dibandingkan tahun $2013 .{ }^{4}$

Pada hasil penelitian dapat dilihat bahwa distribusi usia pasien penyandang epilepsi terbanyak pada golongan usia 1524 tahun $(24 \%)$ diikuti golongan terbanyak kedua pada usia 5-14 tahun (20,80\%), sedangkan golongan usia 65-74 tahun yang paling sedikit $(1,9 \%)$. Hasil penelitian ini sesuai dengan penelitian terdahulu bahwa penyandang epilepsi lebih banyak ditemukan pada golongan usia dewasa muda. ${ }^{4}$ Sekitar 24\% bangkitan baru terjadi setelah usia 60 tahun (lansia) sehingga disebutkan prevalensi epilepsi pada lansia hanya 1,5\% dari jumlah dewasa muda. ${ }^{6}$

Pada Tabel 3 dapat dilihat distribusi penyandang epilepsi berdasarkan tingkat pendidikan terakhir paling banyak ditemukan pada tingkat pendidikan SMA $(34,2 \%)$. Hasil penelitian ini juga sesuai penelitian terdahulu, ${ }^{4,7}$ namun terdapat 2 orang $(1,3 \%)$ penyandang epilepsi yang tidak bersekolah, Hal ini berkaitan dengan pernyataan bahwa anak yang menyandang epilepsi sering tidak disekolahkan atau dikeluarkan dari sekolah karena mendapat serangan kejang. ${ }^{1}$

Berdasarkan distribusi menurut jenis pekerjaan (Tabel 4) didapatkan bahwa penyandang epilepsi banyak ditemukan pada pelajar (32,3\%). Penelitian ini menunjukkan bahwa sebagian besar penyandang epilepsi belum bekerja yang diperjelas dengan data yaitu golongan penyandang epilepsi yang tidak bekerja menempati persentase kedua tertinggi $(12,7 \%)$. Hal ini dapat dipengaruhi beberapa faktor seperti faktor usia, penurunan fungsi kognitif, serta ketidak teraturan pasien terhadap terapi yang diberikan dokter. ${ }^{1}$

Tabel 5 menunjukkan terdapat sebanyak 3 penyandang epilepsi (2\%) dengan kejang terkontrol sedangkan yang lainnya (98\%) dengan kejang yang tidak terkontrol. Hal ini sesuai dengan acuan pustaka bahwa penyandang epilepsi dengan bangkitan yang tidak terkontrol di negara berkembang diperkirakan 6 hingga 10 per seribu penduduk pertahun. ${ }^{7}$

Tabel 6 memperlihatkan jenis bangkitan epilepsi parsial (fokal) ditemukan pada sebanyak 119 penyandang epilepsi $(75,3 \%)$ sedangkan jenis bangkitan umum sebanyak 39 penyandang $(24,7 \%)$. Hasil ini sejalan dengan acuan pustaka bahwa penyandang epilepsi dengan jenis bangkitan kejang fokal lebih banyak dibandingkan dengan jenis bangkitan umum. Kejadian epilepsi parsial sering dihubungkan dengan etiologi seperti trauma kepala, tumor, pasca operasi, gangguan metabolik sistemik, hematoma subdural, infeksi sistem saraf pusat, kelainan degenerative, dan keganasan.

Pada Tabel 7 dapat dilihat distribusi penyandang epilepsi berdasarkan terapi pengobatan yang paling banyak digunakan yaitu fenitoin $(53,2 \%)$, diikuti dengan asam valproate $(21,5 \%)$, dan carbamazepine $(10,1 \%)$. Hasil penelitian ini sesuai dengan acuan pustaka yang menjelaskan bahwa fenitoin, asam valproate dan carbamazepine merupakan obat anti epilepsi (OAE) yang banyak digunakan dalam pengobatan epilepsi. Dosis yang digunakan bervariasi dengan dosis pemeliharaan ditentukan berdasarkan respon pasien. ${ }^{9}$ Pada hasil penelitian ini juga ditemukan sebanyak 9 orang yang diberikan obat anti epilepsi kombinasi carbamazepine dan fenitoin. Idealnya pemberian jenis obat tergantung pada tipe epilepsi dan bangkitan.

\section{SIMPULAN}

Dari hasil penelitian yang dilakukan di Poliklinik Saraf RSUP Prof. DR. R. D. Kandou Manado periode Juli 2015-Juni 2016 dapat disimpulkan bahwa jumlah penyandang epilepsi jenis kelamin laki-laki lebih banyak dibandingkan perempuan. Distribusi penyandang epilepsi terbanyak pada golongan usia dewasa muda, tingkat pendidikan terkahir SMA, belum bekerja dan masih berstatus sebagai pelajar, serta mengalami kejang yang tidak terkontrol dengan jenis bangkitan parsial (fokal). 
Jenis terapi obat yang tersering ialah fenitoin dan carbamazepine.

\section{DAFTAR PUSTAKA}

1. Harsono. Buku Ajar Neurologi Klinis. Yogyakarta: Gajah Mada University Press, 2008; p. 119-33.

2. Lukas A, Harsono, Astuti. Gangguan kognitif pada epilepsi. Berkala Ilmiah Kedokteran Duta Wacana. 2016;1:14450.

3. WHO [internet]. Epilepsy: WHO fact sheet; 2016. Available from: http: //www.who.int/mediacentre/factsheets/f s999/en/

4. Khasanah R, Mahama C, Runtuwene $T$. Profil penyandang epilepsi di Poliklinik Saraf RSUP PROF. Dr. R. D. Kandou Manado periode Juni 2013-Mei 2014. eCl. 2015;3:472-6.

5. Nouri SMD. Sudden unexpected death in epilepsy. 2015 Dec 03 [cited 2016]. Available from: http: //emedicine.medscape.com/article/1138 154-overview.

6. Tammasse J. Epilepsi Klinis Diagnostik dan Terapi. Makassar: Masagena Press, 2013; p. 80-1.

7. Gunawan DP, Karema W, Sampoerna JMP. Gambaran tingkat pengetahuan masyarakat tentang epilepsi di Kelurahan Mahena Kecamatan Tahuna Kabupaten Sangihe. eCl. 2016;2(1).

8. Husam, Endang. Perbedaan usia dan jenis kelamin pada jenis epilepsi di RSUP. Dr. Kariadi [Karya Tulis Ilmiah]. Semarang: Universitas Diponegoro; 2008.

9. Tate SK, Depondt C, Sisodiya SM, Cavalleri GL, Schorge S, Soranzo S, et al. Genetic predictors of the maximum doses patients receive during clinical use of the anti-epileptic drugs carbamazepine and phenytoin. PNAS 2005;102(15):5507-12. 